\title{
Correlation Between Anxiety Scores and Tuak Drink Consumption Scores in Batak Tuak Drinker
}

\author{
Rudy Yusuf ${ }^{* 1}$, M. Surya Husada ${ }^{2}$, Bahagia Loebis ${ }^{2}$, Daniel Ginting ${ }^{3}$ \\ ${ }^{1 *}$ Psychiatry Resident, Departement of Psychiatry, Faculty of Medicine, Universitas Sumatera Utara, Dr. \\ Mansyur Street No.58, Merdeka, Medan Baru District, Medan, North Sumatra 20153 \\ ${ }^{2,3}$ Department of Psychiatry, Faculty of Medicine, Universitas Sumatera Utara, Dr. Mansyur Street No.58, \\ Merdeka, Medan Baru District, Medan, North Sumatra 20153 \\ ${ }^{3}$ Departement Public Health, University Of Sari Mutiara Indonesia, Kapten Muslim Street No.79 Medan.
}

\begin{abstract}
Background

In Indonesia, particularly among Bataknees men in Medan, tuak has been known as a staple, enjoyed by mostly men to strengthen their brotherhood. Concurrent Anxiety Disorders and Alcohol Use Disorders (AUD) are relatively common and closely related to the presentation of complex clinical symptoms that warrant an appropriate diagnosis and treatment.

Method

Sixty tuak drinkers from 4 districts of Medan were recruited by using a cluster sampling method. Participants aged 25-55 years old with inclusion criteria were Batak men who drank Tuak, minimum education by completing junior high school and history of drinking tuak took less than 12 months, and AUDIT cutoff value less than or equal to 7. This study's exclusion criteria were no history of psychiatric and general health disorders in the subject.

Result

The results of this study found a significant relationship between the HADS-A score and the AUDIT total score. Also found a significant relationship between the drinking frequency score, the drinking quantity score, the frequency score of heavy drinking, and the HADS-A score.

\section{Conclusion}

The results of this study are essential evidence to promote mental health in the future, especially in the city of Medan.
\end{abstract}

\section{Keywords : Anxiety, Tuak, Batak}

\section{Introduction}

Alcohol is one of the most misused substances or drugs and one of the leading causes of disability and mortality, accounting for 6-9 percent of all fatalities. ${ }^{1}$ The use of hazardous alcohol is one of the most critical risk factors for people's health around the world, has a direct impact on sustainable health development targets (SDG's), including maternal and child health, infectious diseases (HIV, viral hepatitis, tuberculosis), non-communicable and mental health, injury and poisoning. According to the "World Alcohol and Health Report, 2018" released by the World Health Organization (WHO), more than 2.5 billion people drink alcohol worldwide. The global average daily consumption of pure alcohol is 32.8 grams, while in Africa, it exceeds 40 grams per day. On the other hand, alcohol consumption in Southeast Asia is 26.3 grams per day, 20\% lower than the global average. In addition, $44.8 \%$ of registered alcoholic beverages are spirits, $34.3 \%$ beer, and $11.75 \%$ wine. $^{2}$

According to Riskesdas (2018), the national prevalence of drinking alcohol in the Indonesian population aged over ten years in the previous month was $3.3 \%$, with males drinking the most $(6.1 \%)$ and the 20-24 year age group drinking the most $(6.4 \%)$. Several provinces, like North Sulawesi $(16.0 \%)$, East Nusa Tenggara $(15.6 \%)$, and Bali, have a high incidence of alcoholic drinks (14.0\%). In 2018, the prevalence of 
alcoholic beverages in North Sumatra was $5.5 \%$, or around $2.2 \%$ more than the national average. Beer, wine/Arak, whiskey, traditional hazy drinks, clear traditional drinks, and oplosan drinks are the most popular alcoholic beverages among Indonesians over the age of ten. ${ }^{3}$

Tuak is a traditional Batak alcoholic beverage made from palm sugar (Arenga pinnata). There are two varieties of tuak produced throughout the production process: sweet palm wine and bitter palm wine (containing alcohol). In the afternoon, Batak men meet in Lapo Tuak (taverns) to consume traditional alcohol (Tuak). Tuak consumption is unrelated to the socioeconomic level in Medan City. Tuak is offered during traditional Batak gatherings to commemorate ancestral spirits, the deceased, and others. In two traditional formal rituals, such as the Manuan ompu-ompu Ceremony and the Manulangi Ceremony, Tuak utilizes a typical drink. ${ }^{4}$

Anxiety and alcohol use disorder (AUD) are both very prevalent disorders with diverse clinical presentations. Clinicians must have a thorough grasp of the genesis and course of these two diseases to provide an accurate diagnosis and treatment strategy. Standard treatments for anxiety or alcohol use disorder (AUD) must be adjusted and integrated to address the particular needs of these two diseases' patients. ${ }^{5}$

According to a study by Roger et al., in Canberra, Australia, 2000, stated that high drinking consumption, total AUDIT score, and AUDIT problem score were associated with a high negative affect score on participants under 60 years of age (OR in the range $1 \pm 80 \pm 2 \pm 83$ ), abstainers, heavy drinkers. It increases the risk of developing symptoms of anxiety and depression. ${ }^{6}$

According to a study by Caldwell et al., in Canberra, Australia, 2001. They found there was a gender difference in alcohol consumption and mental health. Depression, anxiety, and affect positively correlated significantly with consumption levels for men. Both non-occasional and dangerous drinkers had higher depression and anxiety scores and lowered positive affect scores than light drinkers. A negative affect was not associated with the level of alcohol consumption in men $(p=0.226)$. Alcohol consumption was not associated with anxiety $(p=0.375)$ or positive affects $(p=0.274){ }^{7}$

According to a study by Hayness et al., in Bristol, England, 2005. They found hazardous and dependent drinking was not associated with the onset of anxiety and depression at follow-up, binge drinking was not significantly related to the incidence of anxiety and depression (adjusted OR $=1,36.95 \%, 0.74-2.50 \mathrm{CI}$ ). Anxiety and depression or sub-threshold symptoms were not associated with dangerous incidents or binge drinking at follow-up. Still, there was weak evidence linking threshold symptoms of the onset of alcohol dependence (adjusted OR $=2.04,95 \%$ CI 0.84-4.97). ${ }^{8}$

According to a study by Johannessen et al., in Norway, 2017. They found that symptoms of severe depression are linked to the beginning of drinking, frequency of drinking, and drunkenness. They also reported that women had a higher relationship between anxiety, depressive symptoms, and early onset of drinking than males ( $p$ values for statistical interactions with sex were 0.01 and 0.04 , respectively). ${ }^{9}$

According to a study by Ke-Hsin et al. in Korea, 2018. They found daily alcohol consumption to moderate the relationship between anxiety and sleep quality and avoid alcohol abuse to treat poor sleep quality or anxiety. ${ }^{10}$

\section{Method}

\section{Study design}

This research was an analytic cross-sectional study to determine the correlation between the anxiety score and total AUDIT score of traditional drinks alcohol and the correlation between the frequency, quantity, and excessive drinking of tuak with symptoms of anxiety for Batak Ethnic at Lapo Tuak, Medan City. ${ }^{11,12}$

\section{Research subject}

Sixty tuak drinkers from 4 districts of Medan were recruited by using a cluster sampling method by randomly selecting three lapo for every four districts; Medan Helvetia, Medan Tuntungan, Medan Petisah, and Medan Selayang. In each district, 15 samples were recruited, and 60 samples were gathered in this study. Participants aged 25-55 years old with inclusion criteria were Batak men who drank Tuak, minimum education by completing junior high school and history of drinking tuak took less than 12 months, and AUDIT cutoff value less than or equal to 7. This study's exclusion criteria were no history of psychiatric and general health disorders in the subject. Collecting data was in Lapo Tuak reports on Medan city and conducting a semi-structured interview using the Mini International Neuropsychiatric Interview International Classification of Disease -10 (M.I.N.I. ICD-10), then filtered using inclusion and exclusion 
criteria. Male Batak in Lapo Tuak, Medan city, who met the inclusion criteria, filled in a written agreement after receiving a detailed and clear explanation from participating in the study until 60 subjects were fulfilled. An AUDIT questionnaire was assessed in the interview and followed by an assessment of the H.A.D.S. - Anxiety Subscale questionnaire. ${ }^{13}$

\section{Outcome measure}

\section{Hospital Anxiety and Depression Scale (HADS)}

Zigmond and Snaith first developed the Hospital Anxiety and Depression Scale (H.A.D.S.) in 1983 to identify anxiety disorders and depression among non-psychiatric hospitals. The H.A.D.S. divide into the Hospital Anxiety and Depression Scale-Anxiety (HADS-A) for the anxiety scale and the Hospital Anxiety and Depression Scale-Depression (HADS-D) for the depression scale. Both HADS-A and HADS-D have a sensitivity and specificity of 0.80. The Hospital Anxiety and Depression Scale are designed to provide a simple and reliable measurement tool in medical practice. The term "Hospital" in the title suggests that it is only valid in that setting, but numerous studies conducted worldwide have confirmed that it is valid when used in the community and in practicing medical services. H.A.D.S. only takes 2-5 minutes to complete. ${ }^{14}$

The Hospital Anxiety and Depression Scale consist of 14 statements which divided into two scales, namely to assess anxiety (7 statements) and depression (7 statements), in which the patient classifies each statement of four value scales, from a value of 0 (not at all) up to a value of 3 (very often). A higher value indicates a problem. Subjects' answers were summed separately, namely ratings for anxiety and ratings for depression, with the minimum and maximum numbers being 0 and 21 for the scales, respectively. The recommended intercepts are more than or equal to 16, representing a severe case, the 11-15 cutoff is moderate, the 8-10 cutoff is a mild case, and less than 8 is not a case of anxiety/depression. The H.A.D.S. validity and reliability had been reported in several studies. In Indonesia, Widyadharma et al. Reported a reliability test for H.A.D.S. in 2015. The result of the interrater agreement on HADS-A was 0.706. The result of the interrater agreement on HADS-D is 0.681 . Where the value $0.61-0.80$ means the reliability is good. ${ }^{15}$

\section{Alcohol Use Disorder Identification Test (AUDIT)}

The Alcohol Use Disorder Identification Test (AUDIT) is developed to filter out excessive drinking and, in particular, to help clinicians identify people who would benefit from cutting back or stopping drinking. The majority of individuals with excessive drinking remain undiagnosed. They often present with symptoms or problems that are usually not related to their drinking habits. Therefore, AUDIT serves to assist clinicians in identifying whether the individual is at risk or is alcohol dependent. ${ }^{16}$

The Alcohol Use Disorder Identification Test (AUDIT) consists of 10 questions that are scored from 0-4. The AUDIT questionnaire is divided into three primary domains that assess alcohol use: the use of hazardous alcohol, symptoms of dependence, and alcohol abuse. AUDIT's cutoff value is 8 points, which has a sensitivity of 0.9 and a specificity of 0.8. A total AUDIT score of 8 indicates alcohol use, alcohol abuse, or alcohol dependence. [12,13] Alcohol Use Disorder Identification Test (AUDIT) has been validated in the Indonesian version with reliability (Cronbach's alpha) of $0.859(\mathrm{r}=0.559-0.795, \mathrm{p}<0.001) .{ }^{17}$

\section{Statistical Analysis}

In this study, we used the P.A.S.W. version of S.P.S.S. Statistics. 20.0 (S.P.S.S. Inc., Chicago, IL, U.S.A.) for statistical analysis with static significance $(\mathrm{p}$-value $<0.05)$ for all statistical tests. The analysis test has been carried out on the variable total score AUDIT and the HADS-Anxiety Scale score. The normality test of the data was carried out using the Kolmogorov-Smirnov test because the number of samples was 60 ( $\mathrm{n}>$ 50) with a p-value $>0.05$. Since the data in this study were not normally distributed, the numerical variables in this study were then presented in the median (minimum-maximum). At the same time, the categorical variables were presented in the form of numbers and percentages. This study uses the Spearman correlation test because the dependent and independent variables were not normally distributed, and the linearity requirements were met. ${ }^{18,19}$

\section{Patient Consent Form}

All research subjects were asked to fill out written consent to participate in the study after being given a detailed and clear explanation about this research. 


\section{Research Ethics}

This research follows the pattern and norms of formal scientific studies. On the part of the interviewed participants, the researcher explained that the author would guarantee their information and data confidentiality. This research has been approved by the Health Research Ethics Committee, Faculty of Medicine, University of North Sumatra/H. Adam Malik General Hospital.

\section{Results}

The characteristics of the research subjects can be seen in Table 1. The study found that the median age of traditional alcohol drinkers (tuak) among the Batak ethnic in Medan City was 38.5 years (25-55 years), most of the marital status was married, most of them had a high school education and mainly were workers. The mean HADS-Anxiety Scale Scores were 7.27 \pm 2.510 . The median of AUDIT Total Score, Frequency of the Tuak Drinks Score (the Questionnaire No. 1 AUDIT), Tuak Drink Quantity's median Score (Questionnaire No. 2 AUDIT), and Frequency of Heavy Drinking in Tuak (Questionnaire No. 3 AUDIT) are 6.00 (4-7), 4 $(2-4), 1(1-2)$ and $1(0-2)$.

Table 1 Demographic characteristics of Batak Men $(n=60)^{\mathrm{a}}$

\begin{tabular}{|l|c|c|}
\hline \multicolumn{1}{|c|}{ Demographic characteristics } & Mean \pm S.D. & n (\%) \\
\cline { 2 - 3 } & Median (min-max) & \\
\hline Age (years) & $38.50(25-55)^{\mathrm{a}}$ & \\
\hline Duration of drinking tuak (months) & & \\
\hline Marital status & & $49(81.7)$ \\
\hline Married & & $11(18.3)$ \\
\hline Not Married & & $2(3.3)$ \\
\hline Education Level & & $32(53.3)$ \\
\hline Middle School & & $26(43.4)$ \\
\hline High School & & $32(63.3)$ \\
\hline University & & $22(36.7)$ \\
\hline Employment Status & & \\
\hline Employed & & \\
\hline Unemployed & $7.00(3-8)$ & \\
\hline Total AUDIT Score & $4 \pm 2.510$ & \\
\hline HADS-Anxiety Scale Score & $1(1-4)$ & \\
\hline Tuak Drinks Frequency Score (Questionnaire No. 1 AUDIT) & $1(0-2)$ & \\
\hline Tuak Drink Quantity Score (Questionnaire No. 2 AUDIT) & & \\
\hline $\begin{array}{l}\text { Frequency of Excessive Drinking of Tuak Drinks score } \\
\text { (Questionnaire No. 3 AUDIT) }\end{array}$ & & \\
\hline
\end{tabular}

${ }^{a}$ Kolmogorov - Smirnov test

Table 2 shows the correlation test results for the total AUDIT score and the HADS-Anxiety scale score obtained $\mathrm{p}=0.001(\mathrm{p}<0.05)$ with $\mathrm{r}=0.432$. Furthermore, it was concluded that there was a significant relationship between the total AUDIT score and the HADS-Anxiety scale score. The strength of the relationship between both variables is 0.432 , which shows a positive correlation. With these results, this study states that the higher the total AUDIT score, the higher the HADS-Anxiety scale score.

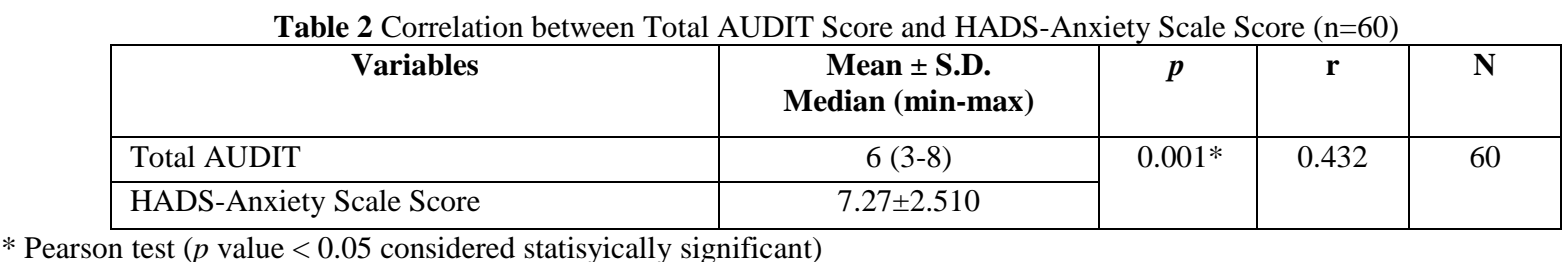

Table 3 shows the correlation test results for the Tuak Drinks Frequency Score (Questionnaire No. 1 AUDIT) and the HADS-Anxiety scale score obtained $\mathrm{p}=0.0015(\mathrm{p}<0.05)$ with $\mathrm{r}=0.312$. Furthermore, it was concluded that there was a significant relationship between the Tuak Drinks Frequency Score (Questionnaire No. 1 AUDIT) and the HADS-Anxiety scale score. The strength of the relationship between both variables is 0.312 , which shows a positive correlation. With these results, this study states that the higher the Tuak Drinks Frequency Score (Questionnaire No. 1 AUDIT), the higher the HADS-Anxiety scale score.

Table 3 Correlation between the Tuak Drinks Frequency Score (Questionnaire No. 1 AUDIT) and HADS-Anxiety Scale Score (n=60)

\begin{tabular}{|l|c|c|c|c|}
\hline \multicolumn{1}{|c|}{ Variables } & $\begin{array}{c}\text { Mean } \pm \text { S.D. } \\
\text { Median (min-max) }\end{array}$ & $\mathbf{p}^{*}$ & $\mathbf{r}$ & $\mathbf{N}$ \\
\hline Tuak Drinks Frequency Score & $4(2-4)$ & $0,015^{*}$ & 0,312 & 60 \\
\hline
\end{tabular}




\begin{tabular}{|l|c|c|c|c|}
\hline (Questionnaire No. 1 AUDIT) & & & & \\
\hline HADS-Anxiety Scale Score & $7.27 \pm 2.510$ & & & \\
\hline
\end{tabular}

* Pearson test ( $p$ value $<0.05$ considered statisyically significant)

Table 4 shows the correlation test results for the Tuak Drinks Quantity Score (Questionnaire No. 2 AUDIT) and the HADS-Anxiety scale score obtained $\mathrm{p}=0.043(\mathrm{p}<0.05)$ with $\mathrm{r}=0.263$. Furthermore, it was concluded that there was a significant relationship between the Tuak Drinks Quantity Score (Questionnaire No. 2 AUDIT) and the HADS-Anxiety scale score. The strength of the relationship between both variables is 0.263 , which shows a positive correlation. With these results, this study states that the higher the Tuak Drinks Quantity Score (Questionnaire No. 2 AUDIT), the higher the HADS-Anxiety scale score.

Table 4 Correlation between the Tuak Drinks Quantity Score (Questionnaire No. 2 AUDIT) and HADS-Anxiety Scale Score ( $\mathrm{n}=60$ )

\begin{tabular}{|c|c|c|c|c|}
\hline Variables & $\begin{array}{c}\text { Mean } \pm \text { S.D. } \\
\text { Median (min-max) }\end{array}$ & $\mathbf{p}^{*}$ & $\mathbf{r}$ & $\mathbf{N}$ \\
\hline $\begin{array}{l}\text { Tuak Drink Quantity Score } \\
\text { (Questionnaire No. } 2 \text { AUDIT) }\end{array}$ & $1(1-2)$ & \multirow[t]{2}{*}{$0,043^{*}$} & \multirow[t]{2}{*}{0,263} & \multirow[t]{2}{*}{60} \\
\hline HADS-Anxiety Scale Score & $7.27 \pm 2.510$ & & & \\
\hline
\end{tabular}

* Pearson test ( $p$ value $<0.05$ considered statisyically significant)

Table 5 shows the correlation test results for the Tuak Drinks Quantity Score (Questionnaire No. 2 AUDIT) and the HADS-Anxiety scale score obtained $\mathrm{p}=0.004(\mathrm{p}<0.05)$ with $\mathrm{r}=0.371$. Furthermore, it was concluded that there was a significant relationship between the Frequency of Excessive Drinking of Tuak Drinks Score (Questionnaire No. 3 AUDIT) and the HADS-Anxiety scale score. The strength of the relationship between both variables is 0.371 , which shows a positive correlation. With these results, this study states that the higher the Frequency of Excessive Drinking of Tuak Drinks Score (Questionnaire No. 3 AUDIT), the higher the HADS-Anxiety scale score.

Table 5 Correlation between the Frequency of Excessive Drinking of Tuak Drinks Score (Questionnaire No. 3 AUDIT) and HADS-Anxiety Scale Score $(n=60)$

\begin{tabular}{|c|c|c|c|c|}
\hline Variables & $\begin{array}{c}\text { Mean } \pm \text { S.D. } \\
\text { Median (min-max) }\end{array}$ & $\mathbf{p}^{*}$ & $\mathbf{r}$ & $\mathbf{n}$ \\
\hline $\begin{array}{l}\text { Frequency of Excessive Drinking of Tuak Drinks score } \\
\text { (Questionnaire No. } 3 \text { AUDIT) }\end{array}$ & $1(0-2)$ & \multirow[t]{2}{*}{$0,004 *$} & \multirow[t]{2}{*}{0,371} & \multirow[t]{2}{*}{60} \\
\hline HADS-Anxiety Scale Score & $7.27 \pm 2.510$ & & & \\
\hline
\end{tabular}

* Pearson test $(p$ value $<0.05$ considered statisyically significant $)$

\section{Discussion}

In Table 1, on the demographic characteristics, the study sample's median age for drinking tuak is 38.5 years (25-55). A study by Knychala et al. in 2015 found that the highest drinking age was 30-40 years (33\%), and alcohol consumption increased with age. ${ }^{20}$

Table 3 shows that the Pearson test results obtained $\mathrm{p}$-value $=0.001$, indicating a significant relationship between the total AUDIT score and the HADS-Anxiety Scale Scores. A study by Ke-Hsin et al. in Korea in 2018 found that daily alcohol consumption was positively correlated with anxiety and sleep quality. Daily alcohol consumption shows moderate effects on anxiety and poor sleep quality $(r=0.54, p=0.001) .{ }^{10}$

The median total AUDIT score and HADS-Anxiety Scale Scores are 6.00 (4-7) and 7.27 \pm 2.510 . It means that traditional alcohol drinkers in the study were low-risk alcohol drinkers and the HADS-Anxiety Scale Scores depicted that alcohol drinkers in this study did not experience anxiety disturbances. Several studies have shown that heavy alcohol drinkers have a mean AUDIT score of 9 and impaired anxiety as indicated by HADS-Anxiety Scale Scores $>5 .^{21}$

The Pearson test results obtained a p-value $<0.05$ between frequency, quantity, and excessive drinking score with the HADS-Anxiety Scale Scores, indicating a significant relationship between the frequency, quantity, and excessive drinking score HADS-Anxiety Scale Scores. A study by Rogers et al. in Canberra, Australia, in 2000 found a significant correlation between age and Goldberg's anxiety and depression scale scores and the total AUDIT score in the hazardous/harmful alcohol consumption group (Anxiety subscale: 1.82). ${ }^{6}$

In this study, it was found that the total AUDIT score was related to anxiety scores. Still, this study shows that daily alcohol consumption was found to moderate anxiety, which is in line with the research of Ke-Hsin et al. in 2018. So this indicates that daily alcohol consumption moderates anxiety. ${ }^{10}$ 
This study also found that the total AUDIT score that affects anxiety scores is also not related to the amount of palm wine consumption in one night following the study of Hayness et al. in 2005 in the UK. This phenomenon may be explained by the variation in the alcohol concentration from $5-20 \%$ in the various traditional alcoholic beverages found throughout the world. Traditional alcoholic drinks, including tuak, are not standardized in alcohol content, so the effects they cause may differ from those of modern alcohol products that are well known. ${ }^{8}$

Another implication of this study is that parents (tuak drinkers) are not bothered by their children drinking tuak during family gatherings; even their children are still considered children. Another fact is that the substance (alcohol) is stored in large quantities without parental supervision, making them drinkers, regardless of whether they are aware that their children consume alcohol.

\section{Recommendation for the further research}

This type of study is so far the first to be carried out in Asia. Meanwhile, our study is limited as it was not conducted with a multi-center approach due to limited resources. Also, by knowing the relationship between anxiety disorders in individuals who consume tuak in Medan City, clinicians and public policy regulators could give more attention to tuak drinkers at risk of experiencing anxiety disorders. This study can provide significant evidence further to tighten the use of regulations on alcoholic beverages.

\section{Conclusions}

This study showed that alcohol intake moderated the correlation between anxiety symptoms among participants who drank tuak (a traditional alcoholic beverage). Alcohol should not treat insomnia or anxiety in drinkers; instead, patients should seek cognitive behavioral therapy and mental health treatments to increase therapy efficacy.

The results of this study are essential evidence to promote mental health in the future, especially in the city of Medan.

\section{Acknowledgments}

We thank all research subjects. Thank also to the Health Research Ethics Committee, Faculty of Medicine, University of North Sumatra / H. Adam Malik General Hospital.

\section{References}

1. Thakkar MM, Sharma R, Sahota P. Alcohol disrupts sleep homeostasis. Alcohol. 2015;49(4):299-310. doi:10.1016/j.alcohol.2014.07.019.

2. World Health Organization. (2018). Global status report on alcohol and health 2018. World Health Organization.

3. RI, D. (2008). Riset kesehatan dasar 2007. Badan Litbang kesehatan Departemen Kesehatan RI. Jakarta: Depkes RI.

4. Conroy DA, Brower KJ. Alcohol, toxins, and medications as a cause of sleep dysfunction. Handb Clin Neurol. 2011;98:587-612. doi:10.1016/B978-0-444-52006-7.00038-1.

5. Ikegami S. Tuak in the Toba Batak Society : A Preliminary Report on the Socio-cultural Aspect of Palm Wine Consumption. Annual Report of the University of Shizouka, Hamamatsu College. 1997 (No. 11-3); $1-8$.

6. Rodgers B, Korten AE, Jorm AF, Jacomb PA, Christensen H, Henderson AS. Non-linear relationships in associations of depression and anxiety with alcohol use. Psychol Med. 2000;30(2):421-432. doi: $10.1017 / \mathrm{s} 0033291799001865$

7. Caldwell TM, Rodgers B, Jorm AF, et al. Patterns of association between alcohol consumption and symptoms of depression and anxiety in young adults. Addiction. 2002;97(5):583-594. doi:10.1046/j.1360-0443.2002.00092.x

8. Haynes JC, Farrell M, Singleton N, et al. Alcohol consumption as a risk factor for anxiety and depression: results from the longitudinal follow-up of the National Psychiatric Morbidity Survey. $\mathrm{Br} J$ Psychiatry. 2005;187:544-551. doi:10.1192/bjp.187.6.544. 
9. Johannessen EL, Andersson HW, Bjørngaard JH, Pape K. Anxiety and depression symptoms and alcohol use among adolescents - a cross sectional study of Norwegian secondary school students. BMC Public Health. 2017;17(1):494. Published 2017 May 23. doi:10.1186/s12889-017-4389-2.

10. Chueh KH, Guilleminault C, Lin CM. Alcohol Consumption as a Moderator of Anxiety and Sleep Quality. J Nurs Res. 2019;27(3):e23. doi:10.1097/jnr.0000000000000300.

11. Dahlan MS. Langkah-langkah membuat proposal penelitian bidang kedokteran dan kesehatan. Seri 3 Edisi 2. Sagung seto. 2016.

12. Sastroasmoro S, Ismael S. Dasar-dasar Metodologi Penelitian Klinis. Edisi 5. Jakarta. Sagung seto. 2016

13. Dahlan MS. Pintu Gerbang Memahami Epidemiologi, Biostatistik, dan Metode Penelitian. Seri 12 Edisi 2. Epidemiologi Indonesia. 2017

14. Snaith RP. The Hospital Anxiety And Depression Scale. Health Qual Life Outcomes. 2003;1:29. Published 2003 Aug 1. doi:10.1186/1477-7525-1-29.

15. Rudy, M., Widyadharma, P. E., \& Adnyana, O. (2015). Reliability Indonesian version of the hospital anxiety and depression scale (HADS) of stroke patients in Sanglah general hospital Denpasar. Research Gate, 2, 1-23.

16. Babor FT, Higgins-Biddle JC, Saunders JB, Monteiro MG. The Alcohol Use Disorders Identification Test : Guidelines for Use in Primary Care, Second Edition. World Health Organization. 2001; 1-40

17. H. Yulianto, H. Pohan, I. Supriyanto, S. H. Ismanto, C. R. Marchira, Validation of the alcohol use disorders identification test (audit) as a screening instrument for alcohol use disorders among prisoners in Lapas Narkotika Klas IIA Yogyakarta, (2017).

18. Dahlan MS. Statistik untuk kedokteran dan kesehatan : deskriptif, bivariat, dan multivariat. Seri 1 Edisi 6. Epidemiologi Indonesia. 2014.

19. Dahlan MS. Besar sampel dalam penelitian kedokteran dan kesehatan. Seri 2 Edisi 4. Epidemiologi Indonesia. 2016.

20. Knychala MA, Jorge ML, Muniz CK, Faria PN, Jorge PT. High-risk alcohol use and anxiety and depression symptoms in adolescents and adults with type 1 diabetes mellitus: a cross-sectional study. Diabetol Metab Syndr. 2015;7:24. Published 2015 Mar 24. doi:10.1186/s13098-015-0020-9

21. Park SY, Oh MK, Lee BS, et al. The Effects of Alcohol on Quality of Sleep. Korean J Fam Med. 2015;36(6):294-299. doi:10.4082/kjfm.2015.36.6.294 